Document downloaded from:

http://hdl.handle.net/10251/67636

This paper must be cited as:

Peinado Pardo, I.; Rosa Barbosa, EM.; Heredia Gutiérrez, AB.; Escriche Roberto, MI.; Andrés Grau, AM. (2013). Optical, Mechanical and Sensorial Properties of Strawberry Spreadable Products Formulated with Isomaltulose. Food and Bioprocess Technology. 6(9):2353-2364. doi:10.1007/s11947-012-0970-y.

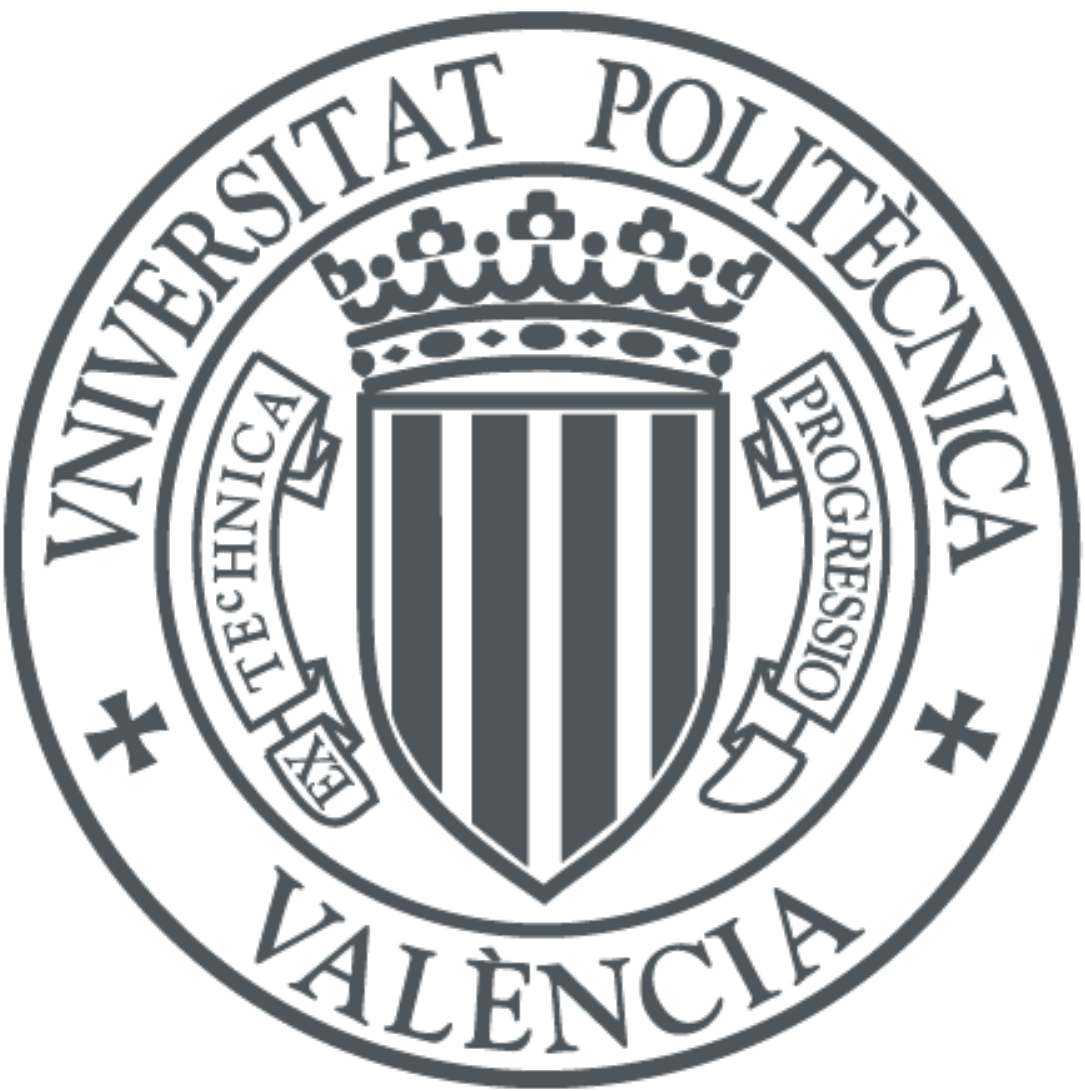

The final publication is available at

https://dx.doi.org/10.1007/s11947-012-0970-y

Copyright Springer Verlag (Germany)

Additional Information 


\title{
OPTICAL, MECHANICAL AND SENSORIAL PROPERTIES OF STRAWBERRY SPREADABLE PRODUCTS FORMULATED WITH ISOMALTULOSE
}

\author{
Peinado, I.; Rosa, E.; Heredia, A.; Escriche, I. * \& Andrés, A.
}

Institute of Food Engineering for Development, Universitat Politècnica de València, P.O. Box 46022 Valencia, Spain

* Corresponding author. Tel.: +34 9638773661; fax: +34 963877369

E-mail address: iescrich@tal.upv.es

\section{Abstract}

Current consumption trends are forcing companies to develop new healthier products to satisfy consumer demand. Therefore, a novel spreadable strawberry product, formulated using osmotic dehydration, with healthy sugars and a high fruit percentage could be an interesting product. Dry Osmotic Dehydration (DOD) can be used to remove water and add sugar in the elaboration of this type of product. Moreover, a concentrated solution rich in volatile compounds, vitamins and water soluble minerals is generated by the water out-flow. The aim of this work was to evaluate the optical and mechanical properties, as well as the sensorial attributes (colour, spreadability, taste with and without bread, cohesiveness and the global preference) of $30^{\circ}$ Brix strawberry spreadproducts. A total of 18 different spread-products were obtained according to the type of sugar (isomaltulose or sucrose), the elaboration method (wet (W) or dry (D) osmotic dehydration with (D1) or without (D2) external liquid phase removal) and the percentage of pectin used for their formulation. The results showed neither influence of pectin percentage nor of type of sugar on the colorimetrical coordinates ( $L^{*}, a^{*}$ and $\left.b^{*}\right)$. Nevertheless, dry osmotic dehydration with external liquid phase removal seemed to better preserve the characteristic fresh strawberry colour. 
27 Regarding texture, lower liquid phase volume and higher fruit-solution ratios led to spread- products with higher consistency and cohesiveness values (consistency values: $5.5 \pm 0.4$ vs $2.9 \pm 0.1$ ( $1 \%$ of pectin), $6.92 \pm 0.08$ vs $4.3 \pm 0.3$ (1.5\% of pectin), $10 \pm$ 1 vs $5.2 \pm 0.3$ ( $2 \%$ of pectin); cohesiveness values: $0.82 \pm 0.07$ vs $0.32 \pm 0.04$ ( $1 \%$ of pectin), $1.21 \pm 0.04$ vs $0.72 \pm 0.08$ (1.5\% of pectin), $1.8 \pm 0.3$ vs $1.00 \pm 0.06(2 \%$ of pectin)), as well as the use of sucrose instead of isomaltulose at $2 \%$ of pectin (consistency values: $9.02 \pm 0.13$ vs $7.9 \pm 0.3$ (W), $11.3 \pm 0.4$ vs $9.60 \pm 0.02$ (D2); cohesiveness values: $1.78 \pm 0.03$ vs $1.56 \pm 0.09$ (W), $2.16 \pm 0.09$ vs $1.80 \pm 0.12$ (D2)). Concerning sensorial evaluation of spread-products formulated with isolmaltulose, the taste was the parameter which conditioned the global preference by panelists. Regarding spreadability, the products ranging from 4 to $5 \mathrm{~N} \cdot \mathrm{s}$ for consistency, and 0.6 to $0.9 \mathrm{~N} \cdot \mathrm{s}$ 38 for cohesiveness were the most appreciated.

Keywords: Isomaltulose, Dry Osmotic Dehydration, optical and mechanical properties, sensory evaluation, Pairwise Friedman ranking test, Correspondence Analysis.

\section{Introduction}

44 Nowadays, consumers want products with good taste and flavour, but moreover, they need to be healthier and with good nutritional and functional value. Besides, these aspects, sometimes it is also required that these food products do not produce undesirable effects, related for example with sugar consumption, as caries and diabetes Pereira et al., 2005; Jeffery et al., 2006; Frank \& Vasanti, 2010; Fraser \& Edwards, 2010; McPhail et al., 2011). Therefore, the development of new products which satisfy consumer expectations is becoming a priority goal of the food industry. 
51 From this point of view, the development of new products such as spreadable fruit could

52 be interesting since they present some characteristics similar to fresh fruit, but on the other hand are more stable than the fresh ones as the $\mathrm{a}_{\mathrm{w}}$ (water activity) and the moisture of the product are reduced. The big difference between a spreadable fruit product and a jam is that in the former, cooking to reach a final soluble solid content is avoided, as it provokes the greatest changes from a nutritional, sensorial and functional point of view. Moreover, a jam must have at least $45^{\circ}$ Brix, whereas a fruit spread does not have any restriction related to sugar content (BOE 04/07/07; RD: 863/2003)

Wet Osmotic Dehydration is a widely extended technique for the processing of fruits and vegetables, due to the high quality of the products obtained when compared with other drying methods (Fito et al., 1998; Lazarides et al., 1999; Nieto et al., 2004; Pani et al., 2008). One of the most important advantages of osmotic dehydration is the use of low temperatures, so that water removal takes place without phase exchange, and therefore damage to colour, taste and aroma is minimized (Moraga et al., 2000; Moreno et al., 2000). Moreover, this technique promotes the biosynthesis of key aroma compounds in fruit such as strawberries (Zabetakis \& Holden, 1997; Escriche et al., 2001; Talens, 2002), pineapples (Pino et al., 1999) and kiwis (Bereiter, 2001). All of this, together with acidity reduction and an increase in the concentration of solutes (sugars), may contribute to improving the taste of acidic and/or sour fruit such as grapefruit.

On the other hand, during osmotic dehydration, besides the loss of water, some natural compounds, such as pigments, aromas, acids, minerals and vitamins are released into the solution (Valdez-Fragoso et al., 1998; Dalla-Rosa \& Giroux, 2001; García-Martínez et al., 2002a). The reutilization of the osmotic solution would mean an accumulation of these compounds and, from this point of view, its use as an ingredient in the formulation 
of new products could be an interesting alternative. In fact, there are some authors who propose osmotic dehydration for the elaboration of jam without heat treatment (Shi et al., 1996; García-Martínez et al., 2002b), and semi-concentrate products (such as canned liquid products, carbonated beverages, fruits juices, etc). (Gonzáles-Mariño et al., 2001, Dalla-Rosa \& Giroux, 2001). However, some disadvantages related to the handling of large volumes of osmotic solutions and high water consumption should be considered. Dry Osmotic Dehydration (DOD) might be an option since the volume of solution generated is considerably lower than the volume managed in the wet method. Previous studies have demonstrated that there is also a greater concentration of aromatic compounds, and soluble vitamins and minerals, as this solution comes from the product itself (Doménech \& Escriche, 2009). DOD consists of covering the product with a solid osmotic agent (avoiding the use of a solution), and leaving this to perform for a period of time provoking the egress of water from the interior of the product. So, as in traditional osmotic dehydration, the obtained product would be more stable than the fresh one as it has decreased moisture content and water activity (Rosa et al., 2008;

91 Peinado et al., 2009).

92 Strawberries are especially interesting because of their content in fibre, minerals, vitamins and other functional compounds such as phenols, many of which have healthy properties. Nevertheless, strawberries in general have a very significant seasonality and a high water content that make them very perishable. Recent food trends (fast food and ready-to-eat food) have resulted in a decrease in the consumption of fresh fruit especially among young people. Although there is a wide range of processed fruit products, such as juices, milky beverages or concentrates, it is important to note that many of them have low fruit content, which in many cases is replaced with a large amount of additives. 
101 On the other hand, since sugar consumption is directly related to health problems like

102 obesity, one of the goals of the food industry is the development of natural sugar control 103 and low glycemic foods (Sloan, 2005; Peinado et al., 2008). Nowadays there are 104 products which replace common sugar with non-caloric sweeteners (glutamate, 105 saccharin, aspartame and polyols (sorbitol) among others). Polyols have a characteristic 106 sweet taste, but the energetic value (calories) of the product is lower when compared 107 with foods containing sucrose (Riku \& Yrjö, 2001). There is another possible sucrose 108 replacer in the market, isomaltulose, which might help to decrease the insulinemic 109 response provoked by other foods. It is found in small amounts in honey and sugar cane 110 (Siddiqui \& Furgala, 1967; Low \& Sporns, 1988; Barez et al., 2000) but can be easily 111 obtained from sucrose by means of an enzymatic process (Weidenhagen \& Lorenz, 112 1957; Mauch \& Schmidt-Berg-Lorenz, 1964; Schiweck, 1980, Schiweck et al., 1990).

113 Finally, it should be said that colour and texture are sensorial parameters of great

114 interest in the food industry since consumers base their choices on the external aspects 115 of the products, and most of the time they look for products similar to the fresh ones. 116 For example, regarding the colour characteristics of this kind of product, a brilliant red 117 colour is desired by consumers who associate this aspect with "freshness" and 118 "healthiness" as opposed to a dark red colour which may led to rejection of the product 119 (Cordenunsi et al., 2003). Moreover, regarding texture, this kind of product usually 120 requires the addition of pectin to achieve an adequate gel consistency, so the amount of 121 pectin depends on the amount of sugars and acids as well as the kind of fruit (Rauch, 122 1987; Gabriele et al., 2001; Renard et al., 2006).

123 The aim of this work was to analyze the influence of processing variables, type of sugar 124 (sucrose or isomaltulose), elaboration method (dry or wet osmotic dehydration, and 125 percentage of fruit), and pectin percentage $(1,1.5$ and $2 \%)$ on the mechanical and 
126 optical properties of $30^{\circ}$ Brix strawberry spreadable products. Sensorial response and

127 analytical data obtained by instrumental measurements were also compared.

\section{Material and Methods}

\subsection{Raw material}

131 Strawberries (Fragaria vesca, Camarosa), acquired in a local supermarket between

132 March and June but always from the same supplier that has different controlled 133 production areas in different zones of Spain. After carrying out a visual selection in

134 terms of colour, shape and level of ripeness to eliminate damaged fruit and homogenise

135 the sample, the strawberries were cleaned and they were cut into cubes of approximately $1361 \mathrm{~cm}^{3}$.

137 Samples were dipped in chlorinated water to eliminate possible pesticide residues, and 138 then they were cut into cubes of approximately $1 \mathrm{~cm}^{3}$.

\section{2.2. Methodology}

140 Figure 1 shows the flow chart of the processing conditions depending on the different

141 variables to get the strawberry spreadable products. As it can be seen, the process was 142 carried on in two stages:

Equilibrium of the samples:

144 Two osmotic agents were used, sucrose (as reference sugar) and isomaltulose (98\%)

145 (Diexpa S.A., Spain). Samples were equilibrated using two osmotic dehydration 146 processes. Wet Osmotic Dehydration (WOD), traditional osmotic dehydration in which 147 samples were immersed in $40^{\circ}$ Brix hypertonic solutions, and Dry Osmotic Dehydration 148 (DOD) in which samples were directly covered with the solid osmotic agent (sucrose or 149 isomaltulose). This last method is similar to the dry salting process commonly applied 150 to meat and fish products. Osmotic dehydration was carried out until samples achieved 
$15130^{\circ}$ Brix (equilibrium concentration). The appropriate fruit-solution ratio was calculated

152 with the correspondent mass balance. The process was carried out $25^{\circ} \mathrm{C}$. The final point

153 control was determined by refractometry measuring the soluble solids concentration in

154 the osmotic solution.

$155 \quad \underline{\text { Jellification }}$

156 Once equilibrium was reached, the dehydrated fruit was separated from the osmotic

157 solution in order to formulate different spreadable products. The ingredients in the

158 formulations were: dehydrated strawberry, osmotic solution, apple pectin $(1,1.5$ or $2 \%)$

159 as a gelling agent and potassium sorbate at a fixed concentration of $500 \mathrm{ppm}$ (as a

160 microbiological preserver) (Karabulut et al., 2001; Castelló et al., 2011). According to

161 the different proportions of dehydrated strawberry-osmotic solution and dehydration

162 method (wet or dry) three different strawberry spreads were elaborated: W, spreads

163 obtained by means of WOD and formulated with a dehydrated fruit-osmotic solution

164 ratio of 70:30; D1, spreads obtained by means of DOD and formulated with the total

165 amount of dehydrated fruit and final osmotic solution obtained and D2, spreads

166 obtained by means of DOD and formulated with a dehydrated fruit-osmotic solution

167 ratio of $70: 30$.

168 Finally, depending on the different variables (type of sugar, elaboration method and

169 pectin percentage) 18 different strawberry spreads were formulated (table 1). Products

170 were homogenized with a mixer for 3 minutes. Then they were stored for 24 hours at 25

$171{ }^{\circ} \mathrm{C}$ to allow correct gel stabilization before performing the analysis. All the analyses in

172 each of the samples were carried out by triplicate. 


\subsection{Analytical determinations}

\subsubsection{Physicochemical analyses}

175 All measurements were carried out in triplicate. Moisture content was determined 176 gravimetrically by drying to constant weight in a vacuum oven at $60{ }^{\circ} \mathrm{C}$ (method 20.103 177 AOAC, 1980). Soluble solids content ( ${ }^{\circ}$ Brix) was measured, in previously homogenized 178 samples, with a refractometer at $20^{\circ} \mathrm{C}($ ATAGO $3 \mathrm{~T})$, (dilution at a ratio of $4 \mathrm{~g}$ water

179 for each gram of sample was necessary). Water activity $\left(\mathrm{a}_{\mathrm{w}}\right)$ was determined with a dew 180 point hygrometer ((FA-st lab, GBX). pH was determined with a pH-meter ( SevenEasy, 181 Mettler Toledo).

182 2.3.2. Colour

183 Instrumental measurements of colour were conducted at room temperature in a Minolta spectrophotometer (model CM-3600d), placing the strawberry spread in a $20 \mathrm{~mm}$ thick, transparent plastic cell and using a black plate as the background to standardize the measurements. Visible absorption spectra were recorded between 380 and $770 \mathrm{~nm}$ by

187 reflectance to obtain tristimulus values of CIEL*a*b*, using illuminant $\mathrm{D}_{65}$ and 188 standard observer $\left(10^{\circ}\right.$ visual field $)$ as references.

190 Objective determinations of strength and consistency were measured with the back-

191 extrusion test using a texturometer TA/XT/PLUS Texture Analyser and the accessory

192 Back extrusion cell with $35 \mathrm{~mm}$ ring (García-Martínez et al., 2002b; Sesmero et al., 193 2007).

194 The back-extrusion test consisted of making a circular base embolus $35 \mathrm{~mm}$ in diameter 195 through the sample contained in a cylindrical glass vessel, at a constant speed of 1

$196 \mathrm{~mm} \cdot \mathrm{s}^{-1}$. For all the assays the embolus covered the same distance to the bottom of the 197 vessel and the amount of sample was the same. 
198 This assay provides a typical curve with two characteristic areas. The above area of the

199 curve $\left(\mathrm{A}_{1-2}\right)$ is taken as a measurement of consistency, while the negative area $\left(\mathrm{A}_{2-3}\right)$ is

200 an indication of the cohesiveness and also consistency/viscosity of the sample (Sesmero

201 et al., 2007).

\subsubsection{Sensory evaluation}

203 A Friedman Pairwise Ranking Analysis was used to evaluate the consumer preferences 204 of the formulations (Meilgaard et al., 1999; Escriche et al., 2001; González-Tomás et al., 2004). This test was chosen as it is particularly useful for a relatively inexperienced panel (non trained panellists) to evaluate sets of three to six samples considering a single attribute each time. 20 subjects constituted the panel which performed the sensory evaluation. The selected samples for this evaluation were presented to each of the subjects, in all possible paired combinations.

210 The selection of the sensory attributes was based on the characteristic criteria of the

211 samples as well as some previous experiments carried out on similar products (Abdullah

212 \& Cheng, 2001; Levaj et al., 2010). The panellists were asked which of the two

213 presented samples they preferred, according to each of the different attributes to be 214 evaluated, in the following order: colour (under white light), spreadability (spreading 215 the product on bread), taste (eating the product with a teaspoon), cohesiveness (sticky 216 feeling in mouth), taste with bread (eating the product once it has been spread on bread)

217 and the global preference.

218 In order to establish the existence of significant differences between the samples, the

219 statistical function T Friedman was calculated by means of equation (I). These results 220 were compared with the tabulated $X^{2}=7.81(\alpha=0.05)$ with $(t-1)$ degrees of freedom 221 (Meilgaard et al., 1999).

$222 \mathrm{~T}=(4 / \mathrm{p} \cdot \mathrm{t}) \cdot \sum_{\mathrm{i}=1}^{\mathrm{t}} \mathrm{R}_{\mathrm{i}}{ }^{2}-\left(9 \cdot \mathrm{p} \cdot[\mathrm{t}-1]^{2}\right)$ 
223 where,

$224 \quad \mathrm{p}=$ number of panellists

$225 \quad \mathrm{t}=$ number of samples $(\mathrm{t}=4)$

$226 \quad \mathrm{R}_{\mathrm{i}}=$ rank sum for each evaluated attribute

227 Afterwards, the HSD (Tukey's honestly significant difference) was calculated to 228 establish between which samples these differences lay, (equation II) (Meilgaard et al., 229 1999):

$230 \quad \mathrm{HSD}=\mathrm{q}_{\alpha, \mathrm{t}, \infty}(\mathrm{p} \cdot \mathrm{t} / 4)^{1 / 2}$

231 where,

$232 \quad \mathrm{q}_{\alpha, t, \infty}=$ value in table T4

$233 \quad \mathrm{p}=$ number of panellists

$234 \mathrm{t}=$ number of samples $(\mathrm{t}=4)$

$235 \quad$ 2.3.5. Statistical analysis

236 Statgraphics Centurion was used to perform the statistical analyses. Analyses of 237 variance (multifactor ANOVA) were carried out to estimate the significance effect of 238 the process variables (kind of sugar, elaboration method and \% of pectin) on the final 239 product. Furthermore a Correspondence Analysis (CA) was performed to establish the 240 relationship between the selected samples and the evaluated sensory attributes. This 241 graphical tool establishes the association structure between categorical variables 242 (McEwan \& Schlich, 1991/92; Guerrero et al., 2010; Beh et al., 2011).

\section{3. Results and Discussion}

\subsection{Physicochemical characterization of spreadable products}

246 The composition of the strawberry spreads in terms of water activity $\left(\mathrm{a}_{\mathrm{w}}\right)$, soluble solids content $\left(\mathrm{x}^{\mathrm{ss}}\right)$, moisture content $\left(\mathrm{x}^{\mathrm{w}}\right)$ and $\mathrm{pH}$ is shown on table 1 . It can be observed that 
there were no significant differences between the different spreads in terms of soluble

249 solids content or $\mathrm{pH}$, as they were all formulated to reach a final concentration of 30

$250 \quad{ }^{\circ}$ Brix. Nevertheless, $\mathrm{a}_{\mathrm{w}}$ exhibited different values depending on the sugar used in the

251 formulation. These differences might be the result of the different configuration of the

252 sugar molecules, so despite the equal molecular size, the higher solubility leads to a

253 reduction of $\mathrm{a}_{\mathrm{w}}$.

3.2. Influence of the formulation on the optical and mechanical properties of the spreadable strawberry products

Table 2 shows the colorimetric coordinates of the different products obtained. In general, the strawberry spreads showed lower values of $\mathrm{L}^{*}, \mathrm{a}^{*}$ and $\mathrm{b}^{*}$ when compared with fresh strawberries, independently of the process variables. Therefore, lower

259 Chroma $\left(\mathrm{C}^{*}=\left(\mathrm{a}^{* 2}+\mathrm{b}^{* 2}\right)^{1 / 2}\right), \mathrm{L}^{*}$ values (darkening of samples) and a slight decrease in 260 hue $\left(\mathrm{h}^{*}=\operatorname{arctg}\left(\mathrm{b}^{*} / \mathrm{a}^{*}\right)\right)$ were observed too. This decrease in the colorimetric

261 coordinates after the formulation process might be due to the higher soluble solids 262 content of strawberry spreads compared with fresh strawberries, and/or the degradation 263 of the red anthocyanin pigments, which are the principal phenolic compounds 264 responsible for the strawberry colour (Francis, 1985). In fact, García-Viguera et al., 2651999 , pointed out that anthocyanins are very sensitive to oxidation when exposed to 266 light and oxygen.

267 As it can be seen, there was no clear trend for the colorimetrical coordinates $\left(\mathrm{L}^{*}, \mathrm{a}^{*}\right.$ and $268 \mathrm{~b}^{*}$ ), with respect to the sugar used or the pectin percentage. On the other hand, the 269 elaboration method D2 (DOD removing liquid phase) seemed to be the method which 270 better preserved the colour of fresh strawberries. Dervisi et al., (2001) point out that the 271 percentage of pectin seems to have an influence on the colour of different jams. 272 Moreover, Withy et al., (1993) suggest that red colour stability is affected by different 
273 factors such as temperature, $\mathrm{pH}$, oxygen concentration, and sugar, acid and metal 274 content. The influence of the different ingredients on the food system does not only 275 depend on their concentration or distribution within the different system phases but also 276 on the different component interactions. This determines the differences in the results 277 shown in this work.

278 Figure 2 shows the values of consistency and cohesiveness of the different evaluated 279 products. As could be expected, the higher the percentage of pectin, the higher the 280 consistency and cohesiveness values. The elaboration method also presented an 281 influence on texture parameters, probably not only because of the different fruit-solution 282 proportions but also because of the different amounts of liquid phase depending on the 283 dehydration methods (WOD or DOD). Lower liquid phase levels and higher fruit284 solution ratios lead to spreadable fruit products with higher consistency and 285 cohesiveness values. Finally there were differences in the mechanical properties 286 depending on the sugar used; the fruit spreads formulated with sucrose being the ones 287 with the highest values for texture parameters. It is important to point out that the 288 differences observed as a result of the different sugars and the different elaboration 289 methods became more important as the pectin percentage increased. Thus, products 290 formulated under D2-S-2 conditions (DOD removing liquid phase- sucrose - $2 \%$

291 Pectin) achieved the highest consistency and cohesiveness values; while jellification of 292 the products containing $1 \%$ of pectin was not enough to give products with similar 293 values of consistency and cohesiveness to those presented by commercial jams. These 294 results suggest different behaviour in the food matrix depending not only on the 295 different ingredients but also on the different proportions and interactions. (Rauch, 296 1987; Dervisi et al., 2001; Renard et al., 2006) 
297 The statistical analyses (ANOVA) confirmed the results discussed above. Table 3

298 shows the statistical results for the homogeneous groups depending on the different

299 process variables. Regarding the colour parameters, it can be said that neither the sugar

300 used nor the pectin percentage had a significant effect $\left(\mathrm{p}_{\mathrm{value}}<0.05\right)$ on the colour of the

301 different products, while the elaboration method seemed to be the only parameter which

302 produced differences in the colorimetric coordinates. As commented above, the D2

303 method seemed to preserve the colour of fresh strawberries best. On the other hand, the

304 sugar used, the elaboration method and the percentage of pectin had a significant effect

$305\left(\mathrm{p}_{\text {value }}<0.05\right)$ on the texture of the different products.

\section{3.3. Sensory evaluation}

307 Of the 18 possible formulations, only four strawberry spreads with isomaltulose were

308 selected to carry out the sensory evaluation (Table 4). Sucrose formulations were not 309 selected for the following reasons: Firstly, the instrumental results did not show

310 important differences between those spreadable strawberry products formulated with

311 sucrose and those formulated with isomaltulose. Secondly, one of the principal interests

312 of this study was to discern the sensory perception of consumers when sucrose was

313 totally replaced with isomaltulose. Finally, it was not considered appropriate to compare

314 sucrose and isomaltulose formulations in terms of sweetness as sucrose is twice as

315 sweet as isomaltulose (Schiweck, 1980; Hawai et al., 1989; Lina et al., 2002). Wet

316 Osmotic Dehydration formulations (W) were not selected as the mechanical and optical

317 results obtained with this method were not very different from those obtained with Dry

318 Osmotic Dehydration eliminating liquid phase (D2). Moreover, the former dehydration

319 method produces much higher volumes of generated osmotic solution, with the

320 consequent disadvantages from an environmental point of view. Finally, products

321 containing $1 \%$ pectin were also avoided as this pectin level produced spreads which 
were not consistent and cohesive enough to allow the typical jelly texture presented by commercial jellies and spreads. Therefore, a total of 6 pairs, corresponding to all the possible pairings of the 4 products, were evaluated by the panellists.

Table 4 shows the results of the pairwise ranking test for the sensory evaluation of the

326 four spreadable strawberry products selected. It shows the number of times that each

327 row sample was preferred to each column sample for each attribute. The first step in the

328 Friedman analysis is to compute the rank sum for each sample. In this case the rank sums were obtained by adding the sum of row frequencies to twice the sum of the column frequencies (Table 5). The most preferred samples have the lowest values on the

331 ranking scale, and the least preferred the highest values, depending on the evaluated

332 attribute. In order to evaluate whether there were significant differences between the

333 four samples for each of the evaluated attributes, the statistical function T Friedman was 334 obtained as mentioned in material and methods (Escriche et al., 2001; González-Tomás 335 et al., 2004). As these $T$ values were higher than the tabulated $X^{2}=7.81(\alpha=0.05)$ in all 336 cases (except for colour), there were significant differences between the four samples

337 for all the other evaluated attributes with a significance level of $95 \%$ (Meilgaard et al., 338 1999).

339 Once it was demonstrated that significant differences existed between the samples, it 340 was necessary to discover where the differences lay. For this reason, the HDS (which 341 indicates whether two samples are significantly different) was calculated, as explained 342 in material and methods. There are significant differences between two spreadable 343 products, for each attribute, when the difference between their rank sum values is higher 344 than the HDS (16.23). On the contrary, when the difference between the rank sum 345 values is lower than the HDS (16.23), there is no significant difference between the two 
346 samples for this attribute. In Table 5, the indices "a" or " $b$ " are used to indicate

347 homogeneous groups (Meilgaard et al., 1999).

348 Regarding colour, panellists did not notice significant differences between the different 349 spreadable products. Nevertheless formulation D1-1.5 was the one with the best 350 evaluated attributes in terms of adhesiveness, taste, taste with bread and global 351 appreciation, though its spreadability obtained the lowest value. This formulation 352 showed significance differences with formulation D2-2 which attained the worst 353 evaluated attributes in terms of adhesiveness, taste, taste with bread and global 354 appreciation, but the best spreadability value. These results were not surprising as they 355 were the spreadable products with the greatest differences in their process variables.

356 A Correspondence Analysis was conducted to better understand the relationship 357 between the preferences of the subjects and the evaluated attributes from a descriptive 358 point of view. Figure 3 shows the two dimension plot of sample scores and compound 359 loadings obtained by means of the correspondence analysis. The first two dimensions 360 explained $95.57 \%$ of the total variance (Dimension 1, 56.61\% and Dimension 2, 38.96

$361 \%)$. The attributes which contribute the most to the global preference "global" were 362 cohesiveness, taste, and taste with bread, as they are located close to each other on the 363 right side of the plot. Given their proximity to these attributes, the spreadable products 364 formulated by means of D1 (Dry Osmotic Dehydration without eliminating liquid 365 phase) were the ones which were preferred. On the other hand, spreadability was the 366 attribute which contributed least to the global preference of the product, this attribute 367 being located on the left side of the plot, together with spreadable products formulated 368 by means of D2 (Dry Osmotic Dehydration eliminating liquid phase). Moreover, there were no differences between the colour of the different formulations (values of $\mathrm{C}^{*}$ and 
$370 \mathrm{~h}^{*}$ were very similar) since this attribute was located at the top of the plot and did not

371 really contribute to the panellists' choices.

372 Finally, with the aim of observing the relation between the mechanical parameters

373 obtained by means of instrumental analyses, and the sensorial preferences, these

374 instrumental values were plotted in Figure 3. It shows, how the most appreciated values

375 of mechanical properties were those ranging from 4 to $5 \mathrm{~N} \cdot \mathrm{s}$ for consistency, and 0.6 to

$3760.9 \mathrm{~N} \cdot \mathrm{s}$ for cohesiveness, while higher values of both parameters were not appreciated

377 by the panellists.

\section{4. Conclusions}

379 The type of sugar, the fruit-solution proportion and the pectin percentage have a high

380 influence on the texture (consistency and cohesiveness) of the spreadable strawberry

381 products. Of these, the sucrose products with more fruit and high pectin percentage had

382 the highest values for texture, as expected. Regarding instrumental measurements,

383 colour does not seem to be affected by the different variables, though the spreadable

384 strawberry products obtained with "Dry Osmotic Dehydration eliminating the liquid

385 phase" (D2), seem to be more similar to fresh strawberries. Global preference was

386 mainly influenced by taste and texture, the most appreciated products being those

387 obtained without eliminating the osmotic solution and containing intermediate levels of

388 pectin. These results suggest that spreadable products made with isomaltulose could

389 have a good acceptability among consumers. Nevertheless, further research would be

390 interesting to establish the self-life of the product. For instance a mild heat treatment

391 such as pasteurization, once the final spread is formulated, may be indicated to give

392 more durability to the product without decreasing its quality.

\section{5. Acknowledgments}


395 Authors would like to thank Dirección General de Investigación del Ministerio de

396 Ciencia y Tecnología (AGL2008-01745/ALI) as well as the Universitat Politècnica de

397 València for the financial support given to this investigation.

398

399 References

400 Abdullah, A. \& Cheng, T. (2001). Optimization of reduced calorie tropical mixed fruit 401 jam. Food Quality and Preference 12, 63-68.

402

Barez, J., Villanova, R., Garcia, S., Pala, T., Paramas, A. and Sanchez, J. (2000).

"Geographical discrimination of honeys througth the employement of sugar patterns and common chemical quality parameters". European Food Research and Technology, 210, pp: 437-444.

Beh, E., Lombardo, R. \& Simonetti, B. (2011). A European perception of food using two methods of correspondence analysis. Food Quality and Preference 22, 226-

408 231.

Bereiter, M. (2001). Effect of osmodehydrofreezzing on quality attributes of kiwi fruit. Trabajo Final de Carrera. Universidad Politécnica de Valencia.

B.O.E. 04/07/07. Real Decreto 863/2003. Norma de calidad para la elaboración, comercialización y venta de confituras, jaleas, mermeladas de frutas y crema de castañas.

414 Castelló, M.L., Heredia, A., Domínguez, E., Ortolá, M.D. \& Tarrazó, J. (2011). Influence of thermal treatment and storage on astringency and quality of a spreadable product from persimmon fruit. Food Chemistry 128, 323-329.

Cordenunsi, B., Nascimento, R. \& Lajolo, F. (2003). Los cambios físico-químicos relacionados con la calidad de cinco cultivares de frutales de fresa en fresco de almacenamiento, Química de los Alimentos 83, 167-173. 
Dalla-Rosa, M \& Giroux, F. (2001). Osmotic treatments and problems related to the solution managament. Journal of Food Enginnering, 49, 223-236.

422

423

424

425

426

427

428

429

430

431

432

433

434

435

436

437

438

439

440

441

442

443

444

445

Dervisi, P., Lamb, J. \& Ioannis Zabetakis. (2001). High pressure processing in jam manufacture: effects on textural and colour properties. Food Chemistry Vol 73, (1), 85-91.

Domenech, E. \& Escriche, I. (2009). Valoración y selección de una técnica de análisis para su uso en la determinación y cuantificación de antioxidantes presentes en la fresa (var. Camarosa) y sus derivados. V Congreso Virtual Iberoamericano sobre Gestión de Calidad en Laboratorios (V IBEROLAB). Ministerio de Agricultura Pesca y Alimentación. Madrid, España. 02/05/2009-30/06/2009. Ed: Ministerio de Agricultura Pesca y Alimentación. CD-rom: 331 - 335.

Escriche, I., Fernández-Segovia, I., Serra, J.A., Andrés, A. \& Barat, J.M. (2001). Evaluación sensorial del bacalao desalado, pretratado térmicamente listo para cocinar. Alimentaria, n 322, 51-54.

Fito, P., Andrés, A., Albors, A. \& Barat, J. (1998). Deshidratación de productos agrícolas: Secado por aire caliente. Servicio de publicaciones de la Universidad Politécnica de Valencia, Valencia, España.

Francis, F. J. (1985). Pigments and colorants. In O.R. Fennema (Ed.). Food Chemestry (pp. 545-584). New York Marcell Dekker, Inc.

Frank, B. H. \& Vasanti, S. M. (2010). Sugar-sweetened beverages and risk of obesity and type 2 diabetes: Physiology \& Behavior 100, 47-54.

Fraser, L. K. \& Edwards, K. L. (2010). The association between the geography of fast food outlets and childhood obesity rates in Leeds, UK. Health \& Place 16, $1124-1128$.

Gabriele, D., De Cindio, B. \& D’Antona, P. (2001). A weak gel model for foods. Rheologica Acta 40, 120-127. 
446 García-Martinez, E.; Martinez-Monzó, J.; Camacho, M.M. \& Martinez-Navarrete, N.

447 (2002a). Characterisation of reused osmotic solution as ingredient in new food $448 \quad$ product formulation. Food Research International, 35, 307-313.

449 García-Martinez, E.; Ruiz-Diaz, J; Martinez-Monzó, J.; Camacho, M.M.; Martinez450 Navarrete, N. \& Chiralt, A. (2002b). Jam manufacture with osmodehydrated fruit . Food Research International, 35, 301-306.

452 García-Viguera, P. Zafrilla, F. Romero, P. Abellán, F. Artés, \& F.A. Tomás-Barberán. (1999). Color Stability of Strawberry Jam as Affected by Cultivar and Storage Temperature. Journal of Food Science, (64) 2, 243-247.

Gonzáles-Mariño, G.; Barat, J.M.; Chiralt, A. \& Fito, P. (2001). Yield increase in osmotic processes by applying vacuum impregnation. In: Osmotic Dehydration and Vacuum Impregnation. Applications in Food Industries. Edited by Pedro Fito , Amparo Chiralt, Jose M . Barat, Walter E . L . Spiess, \& Diana

González-Tomás, L., Carbonell, I. \& Costell, E. (2004). Influence of type, concentration and flow behaviour of hydrocolloid solutions on aroma perception. Eur Food Res Technol (2004) 218:248-252.

463 Guerrero, L., Claret, A., Verbeke, W., Enderli, G., Zakowska-Biemans, S. \& 464 Vanhonacker, F. (2010). Perception of traditional food products in six European regions using free word association. Food Quality and Preference, 21, 225-233.

466 Hawai, K., Yoshikawa, H., Murayam, Y, Okuda, Y \& Yamashita, K. (1989). Usefulness 467 of palatinose as a caloric sweetener for diabetic patients. Hormone and Metabolic Research 21, 338-340. 
Jeffery, R., Baxter, J., Mcguire, M. y Linde, J. (2006). Are fast food restaurants an environmental risk factor for obesity?. International Journal of Behavioral Nutrition and Physical Activity 3(2): 2006.

Karabulut, O. A., Lurie, S., \& Droby, S. (2001). Evaluation of the use of sodium bicarbonate, potassium sorbate and yeast antagonist for decreasing posthavest decay of sweet cherries. Postharvest Biology and Technology, 23, 233-236

Lazarides, H.N., Fito, P., Chiralt, A., Gekas, V. \& Lenart, A. (1999). Advances in osmotic dehydration. En: Minimal Processing of Foods and Process Optimization, Eds.: R.P. Singh \& F.A.R. Oliveira, CRC Press, Boca Ratón, 175200.

Levaj, B., Bunic, N., Uzelac, V. \& Bursackovacevic, D. (2010). Gel Strength and Sensory Attributes of Fig (Ficus carica) Jams and Preserves as Influenced by Ripeness. Journal of Food Science (75), Nr. 2, 120-124.

Lina, B. R., Jonker, G \& Kozianowski, G. (2002). Isomaltulose (Palatinose Re review of biological and toxicological studies). Food and Chemical Toxicology 40, $1375-1381$.

Low, N. and Sporns, P. (1988). "Analysis and quantitation of minor di and trisaccharides in honey, using capillary gas chromatography”. Journal of Food Science, 53, pp: 558-561,

Mauch, W. \& Schmidt-Berg-Lorenz, S. (1964). "Uber den bakteriellenzymatischen Umlagerungsmechanismus Saccharose.Isomaltulose (6-( $\alpha$-D-Glucosyl)DFruktose)". Zeitschrift fur die Zuckerindustrie, 14, 309-315 and 375-383.

McEwan, J. A., \& Schlich, P. (1991/92). Correspondence analysis in sensory evaluation. Food Quality and Preference, 3, 23-36. 
McPhail, D., Chapman, G. E. \& Beagan, B. L. (2011). "Too much of that stuff can't be good": Canadian teens, morality, and fast food Consumption. Social Science \& Medicine 73, 301-307.

496

497

498

499

500

501

502

503

504

505

506

507

508

509

510

511

512

513

514

515

516

Meilgaard, M., Civille, G.V. \& Carr, B.T. (1999). Attribute difference test III. Pairwise Ranking Test: Friedman analysis. Sensory Evaluation Techniques. $3^{\text {rd }}$ Edition, 103-106.

Moraga, G., Martinez-Navarrete, N., Martinez-Monzó, J. \& Chiralt, A. (2000). Influence of convective and osmotic drying on some colour and firmness properties of strawberry. In Proceedings of $12^{\text {th }}$ International Drying Symposium, IDS 2000 (P.J.A.M. Kerkhof, W.J. Coumans and G.D. Mooiweer, eds.) CD-ROM, Elsevier Science B. V., Noordwijkerhout, Netherlands.

Moreno, J.; Chiralt, A.; Escriche, I. \& Serra, J.A. (2000). Effect of blanching/osmotic dehydration combined methods on quality and stability of minimally processed strawberries. Food Research. International, 33(7), 609-616.

Nieto, A.B., Salvatori, D.M., Castro, M.A. \& Alzamora, S.M. (2004). Structural changes in apple tissue during glucose and sucrose osmotic dehydration: shrinkage, porosity, density and microscopic features. Journal of Food Technology, 61(2), 269-278.

Pani, P., Leva, A.A., Riva, M., Maestrelli, A. \& Torreggiani, D. (2008). Influence of an osmotic pretreatment on structure-property relationships of air-dehydrated tomato slices. Journal of Food Engineering, 86, 105-112.

Peinado, I.; Rosa, E.; Heredia, A. \& Andrés, A. (2008). Estudio comparativo del color en fresa deshidratada osmóticamente con sacarosa, sorbitol e isomaltulosa. En Actas del V Congreso Español de Ingeniería de Alimentos CESIA 2008. II 

84-96736-57-3).

Peinado, I.; Rosa, E.; Heredia, A. \& Andrés, A. (2009). Influence of Dry and Wet Osmotic dehydration on colour and texture o a spread strawberry product. "New Chalenching in Food Preservation" European Federation of Food Science and Technology (EFFoST). (11-13/11/09), Budapest, Hungary.

Pereira, M., kartashov, A., Ebbeling, C., Van Horn, L., Slattery, M., Jacobs, D. \& 524 Ludwig, D. (2005). Fast-food habits, weight gain and insulin resistance (the CARDIA study): 15-year prospective analysis. The lancet, 365:36-42.

Pino, J.A.; Castro, D.; Fito, P.; Barat, J.M. \& Lopez, F. (1999). Multivariate statistical analysis of volatile compounds as criterion for selecting technological parameters in the osmotic dehydration of pineapple. Journal of Food Quality, 22(6), 653-662.

Rauch, G.H. (1987). Fabricación de mermeladas. Ed. Acribia, S.A. Zaragoza. España.

Renard, D., Van de Velde, F. \& Vischers, R.W. (2006). The gap between food gel structure, texture and perception. Food Hydrocolloids 20, 423-431.

Riku, A. and Yrjö, H. (2001). "Phase and state transition effects on dielectric, mechanical, and thermal properties of polyols". Thermochimica Acta. 380, pp: 109-121,

536 Rosa, E., Peinado, I., Heredia, A. \& Andrés, A. (2008). Deshidratación osmótica de frutas por vía seca. Una alternativa al uso de disoluciones. Póster-Artículo, Concgreso Iberoamericano sobre Seguridad Alimentaria. V Congreso Español de Ingeniería de Alimentos. Book of Abstracts, p. 168. 
Sesmero. R, Quesada, M. A. \& Mercado J. A. (2007). Antisense inhibition of pectate lyase gene expression in strawberry fruit: Characteristics of fruits processed into jam. Journal of Food Engineering, 79, 194-199.

Siddiqui, I. and Furgala, B. (1967). "Isolation and characterization of oligosaccharides from honey. Part I. Disaccharides". Journal of Agricultural Research. 6, 139145 ,

Schiweck, H. (1980). "Palatinit ${ }^{\circledR}$ Herstellung, technologische Eigenschaften und Analytik palatinithaltiger Lebensmittel". Alimenta 19, 5-16.

Schiweck, H., Munir, M., Rapp, K., Schenider, B., \& Bogel, M. (1990). "New developments in the use of sucrose as an industrial bulk chemical". Zuckerindustrie 115, 555-565.

Shi, X.Q.; Chiralt, A.; Fito, P.; Serra, J.A.; Escoin, C. \& Gasque, L. (1996). Application of osmotic dehydration technology on jam processing. Drying Technology, 14(34), 841-857.

Sloan, A. (2005). "Healthy vending and other emerging trends". Food Technology. Vol. 59, 26-35. Thesis, Universidad Politécnica de Valencia.

Valdez-Fragoso, A.; Welti-Chanes, J. \& Giroux, F. (1998). Properties of a sucrose

Weidenhagen, R. \& Lorenz, S. (1957). "Palatinose (6-alpha-Glucopyranosidofructofuranose), ein neues bakterielles Umwandlung-sprodukt der Saccharose”. Zeitschrift fur die Zuckerindustrie, 7, 533-534; und Angewandte Chemie, 69, 641, 
565 Withy, L. M., Nguyen, T. T., Wrolstad, R. E., \& Heatherbell, D. A. (1993). Storage changes in anthocyanin content of red raspberry juice concentrate. Journal of Food Science, 58, 190-192.

568 Zabetakis, I. \& Holden, M.A.(1997). Strawbery flavor: Analysis y biosynthesis. Journal 569 of Agriculture of Food Chemistry 74, 424-434.

570

571 
Table 1. Average physicochemical composition of strawberry spreadable products depending on type of sugar, elaboration method and pectin percentage $(n=3)$.

\begin{tabular}{|c|c|c|c|c|c|c|}
\hline \multicolumn{3}{|c|}{30 Brix } & \multirow[t]{2}{*}{$x^{w}$} & \multirow[t]{2}{*}{$\mathbf{x}^{\mathrm{ss}}$} & \multirow[t]{2}{*}{$\mathbf{a}_{\mathbf{w}}$} & \multirow[t]{2}{*}{$\mathbf{p H}$} \\
\hline Ela & tion & $\begin{array}{c}\% \\
\text { Pectin } \\
\end{array}$ & & & & \\
\hline \multicolumn{7}{|c|}{ Sucrose } \\
\hline 1 & & 1 & $0.665(0.002)$ & $0.320(0.009)$ & $0.952(0.002)$ & - \\
\hline 2 & $\mathrm{~W}$ & 1.5 & $0.6580(0.0004)$ & $0.325(0.004)$ & $0.9550(0.0006)$ & $3.663(0.012)$ \\
\hline 3 & & 2 & $0.6667(0.004)$ & $0.323(0.002)$ & $0.9550(0.0012)$ & $3.56(0.02)$ \\
\hline 4 & & 1 & $0.6703(0.0004)$ & $0.326(0.005)$ & $0.9490(0.0012)$ & - \\
\hline 5 & D1 & 1.5 & $0.6640(0.0009)$ & $0.309(0.006)$ & $0.9480(0.0012)$ & - \\
\hline 6 & & 2 & $0.6688(0.0012)$ & $0.327(0.003)$ & $0.952(0)$ & $3.62(0)$ \\
\hline 7 & & 1 & $0.687(0.002)$ & $0.306(0.002)$ & $0.9530(0.0006)$ & $3.633(0.006)$ \\
\hline 8 & $\mathrm{D} 2$ & 1.5 & $0.6823(0.002)$ & $0.302(0.003)$ & $0.958(0.002)$ & $3.617(0.006)$ \\
\hline 9 & & 2 & $0.663(0.002)$ & $0.26(0.02)$ & $0.9470(0.0012)$ & - \\
\hline \multicolumn{7}{|c|}{ Isomaltulose } \\
\hline 10 & & 1 & $0.73(0.06)$ & $0.31(0.02)$ & $0.9700(0.0006)$ & $3.753(0.006)$ \\
\hline 11 & $\mathrm{~W}$ & 1.5 & $0.6775(0.0012)$ & $0.266(0.006)$ & $0.967(0.002)$ & $3.547(0.012)$ \\
\hline 12 & & 2 & $0.6766(0.0012)$ & $0.29(0.02)$ & $0.971(0.002)$ & - \\
\hline 13 & & 1 & $0.699(0,002)$ & $0.278(0.007)$ & $0.9670(0.0006)$ & $3.580(0.012)$ \\
\hline 14 & D1 & 1.5 & $0.6905(0.0012)$ & $0.293(0.014)$ & $0.968(0.002)$ & $3.637(0.012)$ \\
\hline 15 & & 2 & $0.6890(0.0008)$ & $0.3019(0.003)$ & $0.9640(0.0006)$ & - \\
\hline 16 & & 1 & $0.706(0.005)$ & $0.277(0.003)$ & $0.9640(0.0006)$ & - \\
\hline 17 & D2 & 1.5 & $0.691(0.003)$ & $0.283(0.008)$ & $0.9720(0.0006)$ & - \\
\hline 18 & & 2 & $0.719(0.002)$ & $0.29(0.02)$ & $0.9710(0.0012)$ & $3.660(0.012)$ \\
\hline
\end{tabular}

Mean (standard deviation) 
Table 2 Values of the colorimetrical coordinates $\left(L^{*}, a^{*}, b^{*}\right)$, chroma $\left(C^{*}\right)$ and hue $\left(h^{*}\right)$ of raw strawberries and the different spreadable products depending on the different variables

\begin{tabular}{|c|c|c|c|c|c|c|c|}
\hline & & & $L^{*}$ & $a^{*}$ & $b^{*}$ & $C^{*}$ & $h^{*}$ \\
\hline Raw strawberries & & & $35.77(0.09)$ & $23.1(0.2)$ & $9.98(0.09)$ & $25.2(0.2)$ & $23.3(0.2)$ \\
\hline \multicolumn{8}{|l|}{ Sucrose } \\
\hline 1 & & 1 & $37.211(0.008)$ & $15.6(0.2)$ & $6.42(0.13)$ & $16.9(0.2)$ & $22.3(0.2)$ \\
\hline 2 & W & 1.5 & $31.2(0.2)$ & $17.9(0.3)$ & $7.569(0.108)$ & $19.4(0.3)$ & $22.9(0.4)$ \\
\hline 3 & & 2 & $31.353(0.106)$ & $19.7(0.2)$ & $8.9(0.2)$ & $21.7(0.3)$ & $24.5(0.2)$ \\
\hline 4 & & 1 & $30.1(0.3)$ & $17.2(0.5)$ & $8.5(0.3)$ & $19.2(0.6)$ & $26.33(0.09)$ \\
\hline 5 & D1 & 1.5 & $32.2(0.3)$ & $17.3(0.3)$ & $8.1(0.2)$ & $19.1(0.4)$ & $25.2(0.2)$ \\
\hline 6 & & 2 & $30.31(0.09)$ & $15.39(0.02)$ & $7.0(0.04)$ & $16.90(0.03)$ & $24.428(0.103)$ \\
\hline 7 & & 1 & $31.4(0.2)$ & $18.4(0.5)$ & $7.9(0.2)$ & $20.1(0.5)$ & $23.2(0.2)$ \\
\hline 8 & D2 & 1.5 & $31.3(0.2)$ & $19.2(0.3)$ & $8.4(0.2)$ & $21.0(0.3)$ & $23.6(0.2)$ \\
\hline 9 & & 2 & $33.6(0.4)$ & $18.7(0.7)$ & $8.5(0.4)$ & $20.5(0.8)$ & $24.6(0.2)$ \\
\hline \multicolumn{8}{|l|}{ Isomaltulose } \\
\hline 10 & & 1 & $31.6(0.2)$ & $16.7(0.4)$ & $6.5(0.2)$ & $17.9(0.4)$ & $21.3(0.2)$ \\
\hline 11 & W & 1.5 & $32.2(0.2)$ & $16.7(0.4)$ & $7.7(0.2)$ & $18.4(0.5)$ & $24.8(0.2)$ \\
\hline 12 & & 2 & $33.2(0.3)$ & $17.1(0.2)$ & $7.6(0.2)$ & $18.8(0.2)$ & $23.9(0.5)$ \\
\hline 13 & & 1 & $30.2(0.2)$ & $16.3(0.6)$ & $7.6(0.3)$ & $18.0(0.8)$ & $25.16(0.05)$ \\
\hline 14 & D1 & 1.5 & $30.62(0.05)$ & $17.03(0.13)$ & $7.68(0.14)$ & $18.7(0.2)$ & $24.3(0.2)$ \\
\hline 15 & & 2 & $37.5(0.3)$ & $15.2(0.4)$ & $6.7(0.2)$ & $16.6(0.5)$ & $23.7(0.1)$ \\
\hline 16 & & 1 & $31.4(0.2)$ & $19.3(0.4)$ & $9.0(0.3)$ & $21.3(0.5)$ & $25.1(0.2)$ \\
\hline 17 & D2 & 1.5 & $34.3(0.2)$ & $19.6(0.2)$ & $8.91(0.13)$ & $21.5(0.2)$ & $24.5(0.2)$ \\
\hline 18 & & 2 & $30.38(0.09)$ & $15.30(0.13)$ & $6.09(0.03)$ & $16.5(0.2)$ & $21.7(0.07)$ \\
\hline
\end{tabular}

Variables: elaboration method ( $W$ wet osmotic dehydration, $D 1$ dry osmotic dehydration without eliminating the liquid phase, $D 2$ dry osmotic dehydration eliminating the liquid phase); type of sugar ( $S$ sucrose, $I$ isomaltulose); and pectin percentage $(1,1.5$ and $2 \mathrm{~g} \mathrm{pectin} / 100 \mathrm{~g})(n=3)$ Values are presented as mean (standard deviation) 
Table 3 Homogeneous groups identified from the ANOVA factorial performed depending on the elaboration method (W, D1 or D2); type of sugar (S or I); and pectin percentage $(1,1.5$ and $2 \mathrm{~g}$ pectin/100 g)

\begin{tabular}{|c|c|c|c|c|c|c|}
\hline & \multicolumn{2}{|l|}{ Sugar } & \multicolumn{2}{|c|}{ Elaboration method } & \multicolumn{2}{|c|}{$\%$ Pectin } \\
\hline \multicolumn{7}{|c|}{ Colorimetric coordinates } \\
\hline & $\mathrm{S}$ & $32.1(0.3)(a)$ & W & $32.8(0.4)(a)$ & 1 & $32.0(0.4)(a)$ \\
\hline \multirow[t]{3}{*}{$L^{*}$} & & & D1 & $31.8(0.4)(a)$ & 1.5 & $32.0(0.4)(a)$ \\
\hline & I & $32.4(0.3)(a)$ & D2 & $32.1(0.4)(a)$ & 2 & $32.7(0.4)(a)$ \\
\hline & $\mathrm{S}$ & $17.72(0.13)(b)$ & W & $17.72(0.16)(b)$ & 1 & $17.24(0.16)(a)$ \\
\hline \multirow[t]{3}{*}{$a^{*}$} & & & D1 & $16.40(0.16)(a)$ & 1.5 & $17.96(0.16)(b)$ \\
\hline & I & $17.02(0.13)(a)$ & D2 & $18.41(0.16)(\mathrm{c})$ & 2 & $16.90(0.16)(a)$ \\
\hline & $\mathrm{S}$ & $7.94(0.09)(b)$ & W & $7.47(0.12)(a)$ & 1 & $7.66(0.12)(a)$ \\
\hline \multirow[t]{2}{*}{$b^{*}$} & & & D1 & $7.61(0.12)(a)$ & 1.5 & $8.07(0.12)(b)$ \\
\hline & I & $7.54(0.09)(a)$ & D2 & $8.14(0.12)(b)$ & 2 & $7.48(0.12)(a)$ \\
\hline \multicolumn{7}{|l|}{ Texture values } \\
\hline & $\mathrm{S}$ & $6.4(0.4)(b)$ & W & $6.7(0.5)(b)$ & 1 & $4.6(0.5)(a)$ \\
\hline \multirow[t]{3}{*}{ Consistency } & & & D1 & $4.2(0.5)(a)$ & 1,5 & $6.0(0.5)(b)$ \\
\hline & I & $5.6(0.4)(a)$ & D2 & $7.1(0.5)(b)$ & 2 & $7.4(0.5)(\mathrm{c})$ \\
\hline & $\mathrm{S}$ & $1.12(0.08)(b)$ & W & $1.2(0.1)(b)$ & 1 & $0.7(0.1)(a)$ \\
\hline \multirow[t]{2}{*}{ Cohesiveness } & & & D1 & $0.7(0.1)(a)$ & 1.5 & $1.0(0.1)(b)$ \\
\hline & I & $0.97(0.08)(a)$ & D2 & $1.3(0.1)(b)$ & 2 & $1.5(0.1)(\mathrm{c})$ \\
\hline
\end{tabular}

Values are presented as mean (standard deviation)

$W$ wet osmotic dehydration, $D 1$ dry osmotic dehydration without eliminating liquid phase, $D 2$ dry osmotic dehydration eliminating liquid phase, $S$ sucrose, $I$ isomaltulose

Same letters in parentheses mean no significant difference 
Table 4 Pairwise ranking test: number of times that each row sample was selected as to have better attributes than each column sample

$\begin{array}{llll}\text { D1-1.5 D1-2 } & \text { D2-1.5 }\end{array}$

\section{Cohesiveness}

$\begin{array}{lllll}\text { D1-1.5 } & - & 10 & 17 & 15 \\ \text { D1-2 } & 9 & - & 12 & 16 \\ \text { D2-1.5 } & 2 & 7 & - & 13 \\ \text { D2-2 } & 5 & 4 & 5 & -\end{array}$

Taste

$12 \quad 19 \quad 14$

D1-2

D2-1.5 0

- $\quad 9$

13

D2-2

11

9

13

Colour

D1-1.5

7

13

$$
10
$$

4

D1-2 7

D2-1.5 9

D2-2

Spreadability

D1-1.5

D1-2

D2-1.5

D2-2

$-$

$-$

$9 \quad 9$

119

Taste with bread

\begin{tabular}{lllll} 
D1-1.5 & - & 11 & 16 & 15 \\
D1-2 & 8 & - & 9 & 10 \\
D2-1.5 & 3 & 11 & - & 11 \\
D2-2 & 5 & 8 & 6 & - \\
Global & & & & \\
D1-1.5 & - & 12 & 16 & 13 \\
D1-2 & 8 & - & 9 & 10 \\
D2-1.5 & 4 & 11 & - & 14 \\
D2-2 & 7 & 10 & 5 & - \\
\hline
\end{tabular}

Pectin percentage, 1.5 and $2 \mathrm{~g}$ pectin $/ 100 \mathrm{~g}$

$D 1$ dry osmotic dehydration without eliminating the liquid phase, D2 dry osmotic dehydration eliminating the liquid phase) 
Table 5 Rank of the different attributes obtained by Friedman test

\begin{tabular}{lllll}
\hline & D1-1.5 & D1-2 & D2-1.5 & D2-2 \\
\hline Colour & $76(\mathrm{a})$ & $79(\mathrm{a})$ & $78(\mathrm{a})$ & $82(\mathrm{a})$ \\
Cohesiveness & $74^{\mathrm{a}}(\mathrm{a})$ & $79^{\mathrm{a}}(\mathrm{a})$ & $90(\mathrm{ab})$ & $102^{\mathrm{a}}(\mathrm{b})$ \\
Taste & $73^{\mathrm{a}}(\mathrm{a})$ & $90(\mathrm{ab})$ & $88(\mathrm{ab})$ & $97^{\mathrm{a}}(\mathrm{b})$ \\
Spreadability & $101^{\mathrm{a}}(\mathrm{b})$ & $94(\mathrm{ab})$ & $78^{\mathrm{a}}(\mathrm{a})$ & $78^{\mathrm{a}}(\mathrm{a})$ \\
Taste (bread) & $74^{\mathrm{a}}(\mathrm{a})$ & $87(\mathrm{ab})$ & $87(\mathrm{ab})$ & $91^{\mathrm{a}}(\mathrm{b})$ \\
Global & $79^{\mathrm{a}}(\mathrm{a})$ & $93(\mathrm{ab})$ & $89(\mathrm{ab})$ & $96^{\mathrm{a}}(\mathrm{b})$ \\
\hline
\end{tabular}

Pectin percentage, 1.5 and $2 \mathrm{~g}$ pectin/100g; HSD $=16.2339(p<0.05)$, $q_{\alpha, t, \infty}$ being 3.65

Same letters in parentheses mean no significant difference

$D 1$ dry osmotic dehydration without eliminating the liquid phase, D2 dry osmotic dehydration eliminating liquid phase

${ }^{\text {a }}$ Values in the same row with significant differences (95\%) 


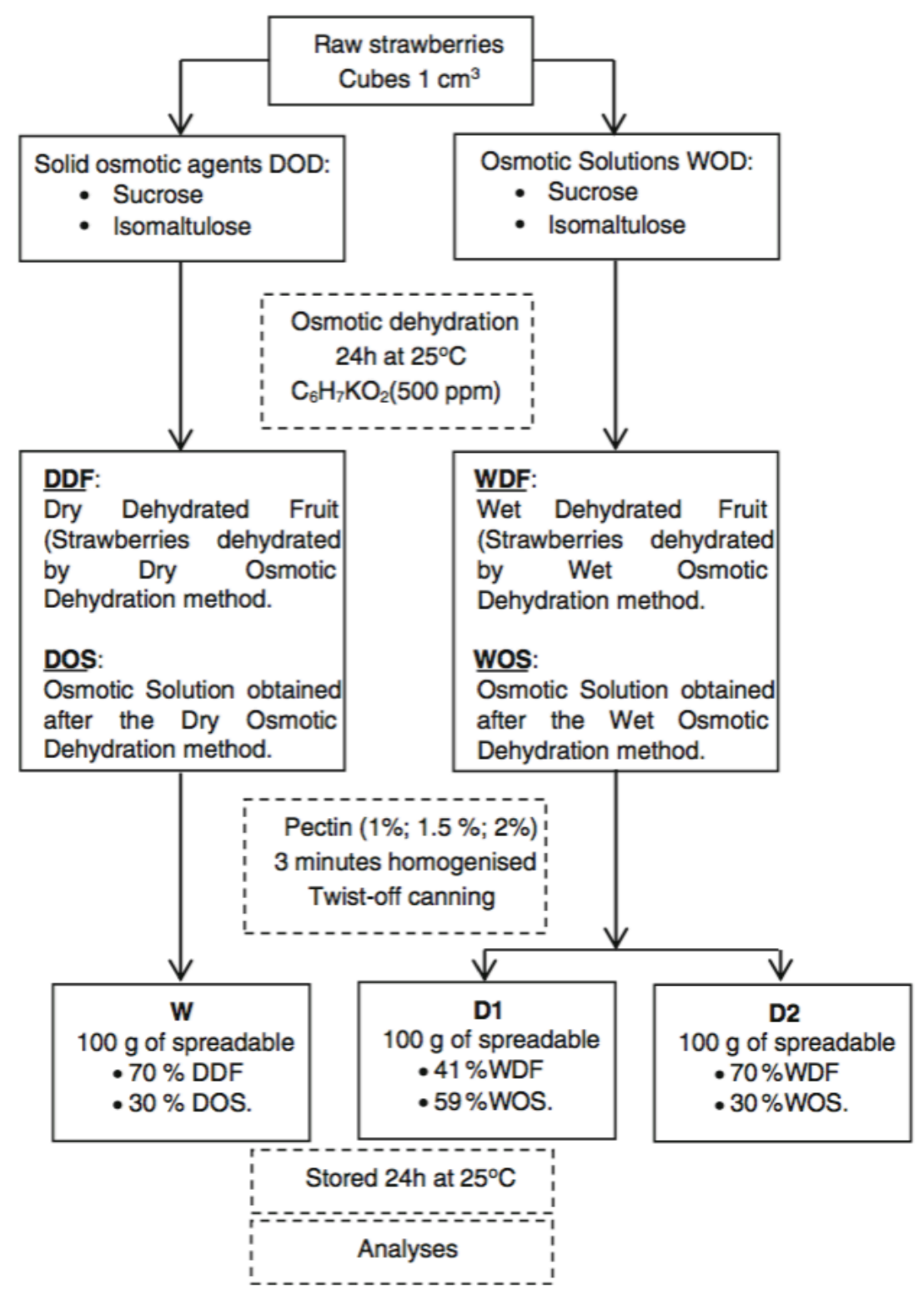

Figure 1: Flow chart of the processing conditions 

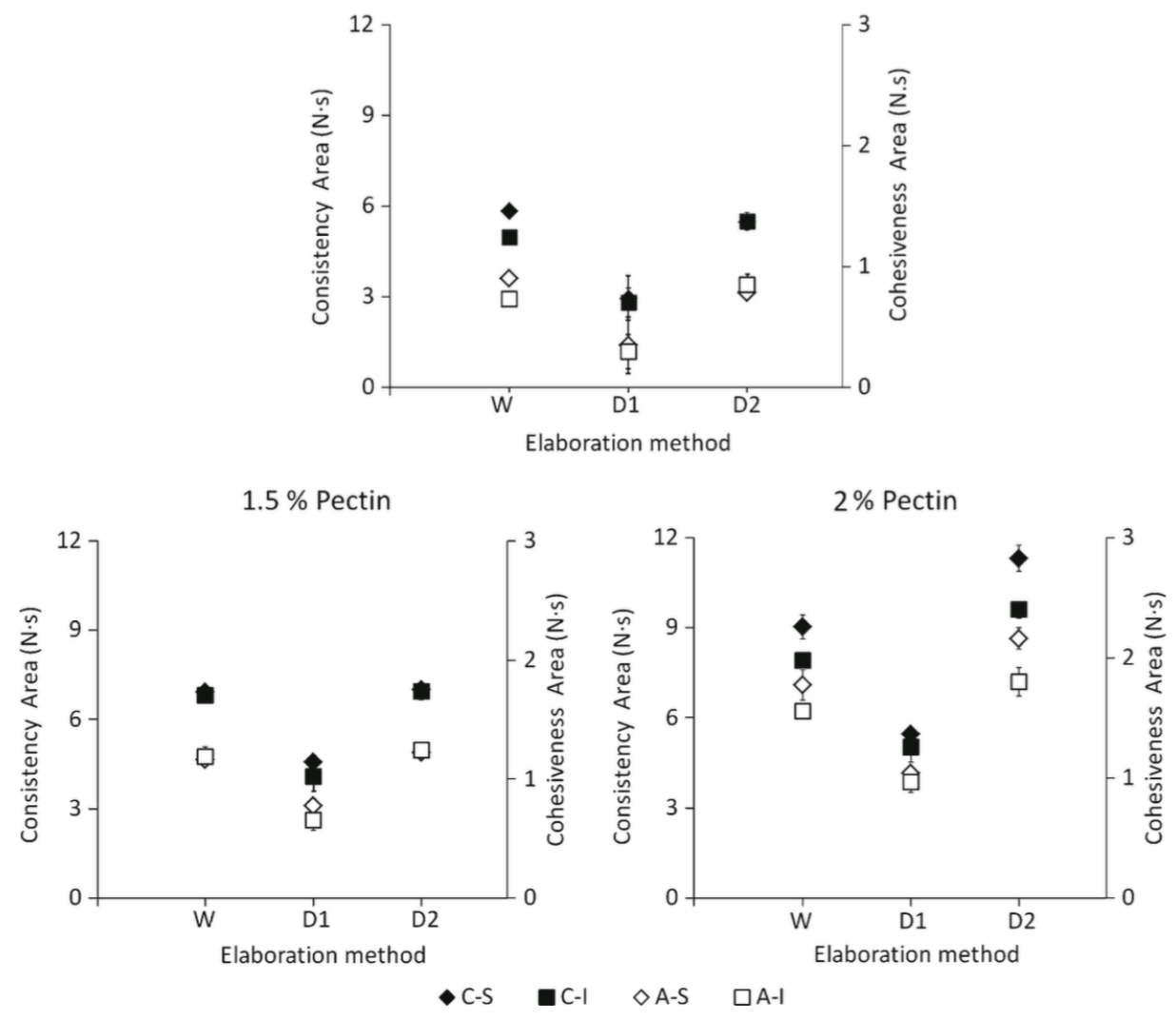

Figure 2: Values of consistency $(\mathrm{C}$ : positive area of curve Force $v s$. time $(\mathrm{N} \cdot \mathrm{s}))$ and cohesiveness (A: negative area of curve Force $v s$. time $(\mathrm{N} \cdot \mathrm{s})$ ) of strawberry spreads considering elaboration method (W: Wet Osmotic Dehydration; D1: Dry Osmotic Dehydration without eliminating liquid phase; D2: Dry Osmotic Dehydration eliminating liquid phase), type of sugar (S: Sucrose; I: Isomaltulose) and pectin percentage (1, 1.5 and $2 \%)$. 


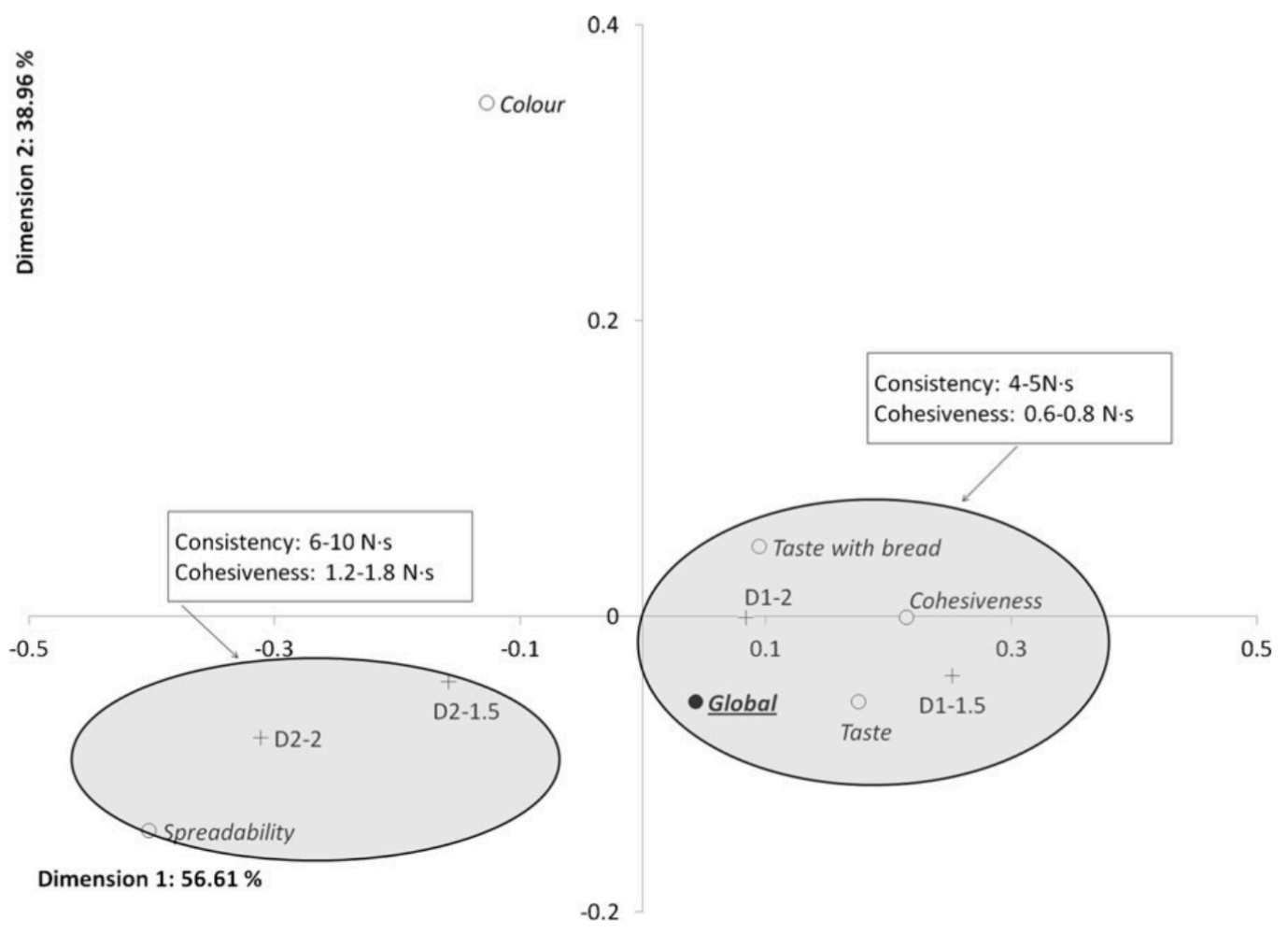

Figure 3: Two-dimensional correspondence plot $(95.57 \%$ of the total variance: Dimension 1, $56.61 \%$ and Dimension 2, $38.96 \%$ ), obtained from performing the correspondence analysis for the four selected samples considering the elaboration method (D1: Dry Osmotic Dehydration without eliminating liquid phase; D2: Dry Osmotic Dehydration eliminating liquid phase), and pectin percentage (1.5 and $2 \%)$. 